\section{Estudo \\ Ecidebate}

em Testã⿻

Plamejamento
Revista Estudo \& Debate, Lajeado, v. 28, n. 4, 2021. ISSN 1983-036X

DOI: http://dx.doi.org/10.22410/issn.1983-036X.v28i4a2021.2846

\title{
O SETOR PETROLÍFERO DO ESTADO RIO DE JANEIRO: UMA ANÁLISE INSUMO-PRODUTO
}

\author{
Marcílio Zanelli Pereira ${ }^{1}$, Leonardo Neves Luz ${ }^{2}$, Giovana Nascimento Pereira ${ }^{3}$
}

\begin{abstract}
Resumo: O estudo tem por principal objetivo analisar os efeitos na economia fluminense de novos investimentos desencadeados pelos leilóes das bacias de petróleo que tem ocorrido desde 1999 e com a previsão de novas rodadas até 2021. A metodologia utilizada foi a de insumo-produto, por permitir capturar os efeitos diretos e indiretos de um aumento da produçáo sobre a economia, bem como analisar o relacionamento entre setores e regiốes. As bases de dados empregadas no estudo foram as matrizes inter-regionais dos anos 2008 e 2011, para as regiôes Restante do Brasil e Rio de Janeiro. Os resultados apontaram que o setor petrolífero do estado do Rio de Janeiro transborda sua produção para os demais setores tanto pelo seu poder de oferta, quanto pela necessidade de consumo. No ano de 2008, o setor se revelou mais influenciador pelo lado da demanda, ao passo que em 2011, se destacou por sua oferta de insumos. O setor também se caracterizou como um setor chave da economia fluminense nos dois anos estudados, já que o mesmo possui capacidade de demandar e ofertar insumos acima da média, comparados aos outros setores. $\mathrm{Na}$ análise inter-regional, o setor petrolífero do Rio de Janeiro mostrou possuir um poder de concentração, mesmo quando a produção não é de origem fluminense.
\end{abstract}

Palavras-chave: setor petrolífero; leilōes da União; Rio de Janeiro; insumo-produto.

\section{OIL AND GAS SECTOR IN RIO DE JANEIRO: INPUT-OUTPUT ANALYSIS}

\begin{abstract}
The main objective of the study is to analyze the effects of new investments on the Rio de Janeiro economy triggered by the oil basin auctions that have been taking place since 1999, with the prediction of new rounds until 2021. The methodology used was the input-output method, because it allows us to capture the direct and indirect effects that the increased production may have on the economy, as well as to analyze the relationship between sectors and between regions. The database used in the study were interregional matrices from 2008 and 2011 for the Rest of Brazil and Rio de Janeiro regions. The results showed that the oil sector of the state of Rio de Janeiro overflows its production to other sectors both for its supply power and for its consumption needs. In 2008, the sector was more influential on the demand side, while in 2011 it stood out for its supply of inputs. The sector was also characterized as a key sector of the Rio de Janeiro economy during the two years studied, since it has the capacity to demand and offer above average inputs compared to other sectors.
\end{abstract}

1 Doutor em Economia (UFJF); Professor Adjunto do Departamento de Economia - UFJF-GV.

2 Doutor em Economia (UFJF); Professor Adjunto do Departamento de Economia - UFJF-GV.

3 Economista-UFJF-GV 
In the interregional analysis, the oil sector of Rio de Janeiro showed that it has a power of sector concentration, even when the production is not originated from the Rio de Janeiro.

Keywords: oil and gas sector; Union auctions; Rio de Janeiro; input-output.

\section{Introdução}

A modificação do sistema adotado pela sociedade pautada em instituiçóes globalizadas e no aumento da competição foi ocasionada pela intensificação dos processos de industrialização e exigiu uma ampliação e diversificação das fontes de energia. Sob esta configuração do sistema produtivo, países com acesso mais barato e fácil às fontes energéticas passariam a ter vantagem comparativa, obtendo ganhos de eficiência. O Brasil, em particular, possui uma vasta gama de recursos naturais com potencial energético e, dentre eles, o petróleo, protagonista entre as matrizes energéticas em função de seu elevado custo-benefício (TOLMASQUIM et al., 2007).

O petróleo é um combustível não renovável, encontrado em áreas térreas ou marítimas, com capacidade de ser facilmente transportado. Sua busca, no Brasil, começou por volta da década de 1860, mas somente em 1939 foram encontradas as primeiras bacias petrolíferas. Com a criação, em 1953, da empresa estatal Petrobras, o governo passou a empregar vultosos esforços na exploração do óleo para diminuir a dependência do Brasil em relação aos países exportadores (DIAS e QUAGLINO, 1993).

A descoberta da maior Bacia de óleo do país, em 1977, transformou o estado do Rio de Janeiro no maior produtor e exportador de petróleo no Brasil, além de receptor das participaçóes governamentais respaldadas pela Lei no 9.478/1997. A mesma lei criou a Agência Nacional de Petróleo (ANP), com o objetivo de fiscalizar o mercado e instituir o fim do monopólio da Petrobras. Desde então, são realizadas licitaçóes públicas para leiloar as áreas de exploração, gerando importantes receitas para o governo (FERNANDES, 2007).

$\mathrm{Na}$ década de 2000, o Brasil aumentou significativamente seu consumo de energia advinda do combustível com o crescimento da população e da quantidade de produtos eletrônicos demandados. Todavia, uma parte importante do combustível consumido internamente ainda era importada. Aumentaram-se, então, os investimentos em pesquisa e desenvolvimento (P\&D) e, em 2006, foi encontrada uma enorme reserva, o chamado Pré-sal (óleo encontrado abaixo da camada de sal marítimo), levando a um aumento na produção (TOLMASQUIM et al., 2007; VIERA FILHO e FISHLOW, 2017).

Quando se examina a cadeia produtiva do petróleo, alguns autores apontam sua importância na geração de empregos diretos e indiretos, no crescimento da renda familiar, no incentivo para inovação das empresas fornecedoras de materiais e aumento de qualificação de pessoal (e.g. PACHECO, 2013; ROFRIGUEZ et al., 2007). Os autores também deixam claro que os efeitos multiplicadores da cadeia produtiva do petróleo são benéficos para a sociedade como um todo. Piquet (2012) ainda aponta os benefícios que podem ser gerados para a sociedade através das arrecadaçóes do governo com os leilóes.

Considerando a importância crescente do setor na economia fluminense, este estudo teve como principal objetivo analisar os efeitos diretos e indiretos produzidos com o aumento na produção do setor do petróleo no estado do Rio de Janeiro. Mais especificamente, o 
trabalho buscou responder às seguintes indagaçóes: i) qual a estrutura de interaçóes entre o setor petrolífero e os demais setores produtivos da economia? ii) qual o impacto de variaçóes na produção do petróleo no estado e no restante do Brasil?

As repostas às questóes ajudam a esclarecer como será o impacto econômico com o crescimento dos investimentos decorrentes dos leilóes promovidos pela União dos campos de produção de petróleo. Além disso, o estudo comparou a estrutura setorial do estado nos anos de 2008 e 2011 para elucidar se houve diferença na relação intersetorial.

Em que pese o estado fluminense ter o terceiro maior número de habitantes do país, o que representava em 2018, aproximadamente, $8,2 \%$ da população brasileira e o segundo maior PIB de 2018 com, aproximadamente, 10,8\% da parcela nacional conforme os dados do IBGE (2021), o estado não apresenta linhas de pesquisa com periocidade contínua em órgãos públicos voltados para análises regionais como destacado em Silva (2006).

Dessa forma, ao permitir analisar de forma pormenorizada a estrutura econômica fluminense e os efeitos spilover que suas atividades produtivas provocam no restante da economia brasileira e no próprio estado, o artigo contribui ao trazer ferramentas que auxiliam os policy maker a diagnosticar os setores-chave para o crescimento econômico e, assim, traçar políticas que permitam o desenvolvimento econômico de forma mais equilibrada. Saber quais setores têm seus insumos demandados ou ofertados para os demais setores pode, entre outros, facilitar no planejamento de políticas que possibilitam prever possíveis gargalos estruturais em setores chaves para o crescimento estadual.

Para alcançar os objetivos propostos, a metodologia utilizada foi a análise de insumoproduto, que permite verificar os efeitos diretos e indiretos na criação de empregos e produto advindos de um crescimento de investimentos no setor petrolífero. Além disso, é possível analisar as relaçóes intra e inter setoriais e os efeitos gerados em diferentes regióes do Brasil.

O trabalho está dividido em cinco seçôes. Além da parte introdutória, foi apresentado um panorama do setor petrolífero, indicando a importância dos leilóes, principalmente para o estado do Rio de Janeiro. A terceira seção refere-se aos aspectos metodológicos, enquanto que os resultados são discutidos na quarta parte. Por fim, são tecidos os comentários finais.

\section{Panorama do setor petrolífero: produção e a importância dos leilóes}

\subsection{O Pré-sal e o Rio de Janeiro}

O petróleo é um combustível fóssil de extrema importância energética para o mundo e é a principal fonte de energia que alimenta a sociedade atual (MARTINS et al., 2015; PEREIRA, 2008; SILVA et al., 2008). Segundo o Governo Federal (2011), é a fonte de energia que possui maior importância geopolítica, uma vez que, seu transporte é fácil de ser realizado e o país que possui controle de reservas têm vantagem comparativa frente aos demais. Martins et al. (2015) descrevem que esse combustível é feito de hidrocarbonetos e é encontrado no subsolo impregnado nas rochas sedimentares em profundidades que variam de poucos metros da superfície podendo chegar em valores superiores a $3 \mathrm{~km}$ abaixo da superfície, tanto em terra firme, quanto em terras submersas. 
Sua importância econômica aumentou significativamente com aumento de escala advindo dos processos industriais que constituíram durante o século XIX (SILVA et al., 2008). Constituiu, ainda, matéria-prima na produção de muitos itens, como combustíveis, componentes bélicos, parafina, plásticos, cosméticos, solventes, dentre muitos outros (MARTINS et al., 2015).

No Brasil, assim como no resto do mundo, a exploração se iniciou no século XIX e, por volta de 1864, pequenos exploradores obtiveram a concessão do governo imperial para procurar o óleo. Transcorreram, no entanto, 60 anos desde a descoberta do combustível no mundo e o petróleo ainda não havia sido encontrado em grande escala no país. Percebendo o atraso em relação aos outros países e a preocupação com a dependência das importaçóes, o governo brasileiro decidiu, em 1919, participar das exploraçóes diretamente, todavia, sem êxito. Em 1938, o presidente Getúlio Vargas decidiu ampliar a intervenção no setor e criou o Conselho Nacional do Petróleo (CNP) para coordenar as políticas do petróleo, com a função inicial de incrementar as buscas pelo recurso e, posteriormente, pela fiscalização desse mercado. No ano seguinte, foi descoberto o primeiro campo de petróleo em LobatoBA e, em 1941, em Candeias-BA (DIAS e QUAGLINO, 1993; MORAIS, 2013; VIERA FILHO e FISHLOW, 2017).

Segundo Vieira Filho e Fishlow (2017), a dependência do país ainda era grande em relação às importaçôes de petróleo, o que fez com que Getúlio Vargas criasse a Petrobras em 3 de outubro de 1953, com a intenção de diminuir os impactos sofridos no país através da produção de petróleo em nível comercial. A empresa era um monopólio governamental no qual o Estado detinha a exclusividade na área da pesquisa, produçáo, refino e transporte. Em 1966 foi criado o Centro de Pesquisas e Desenvolvimento Leopoldo Américo Miguez de Mello (Cenpes), da Petrobras, para realocar os investimentos em terra para a costa marítima, dado o entendimento da insuficiência da produção em áreas térreas para o suprimento da demanda nacional. Na década de 1970, foi descoberta a primeira offshore, comprovando a presença de óleo embaixo da plataforma continental.

Sob as duas crises do petróleo (1973 e 1979) ${ }^{4}$, a oferta de petróleo foi fortemente afetada. O Brasil ainda importava cerca de $70 \%$ do consumo interno, reduzindo, assim, as opçóes para o consumo e impactando fortemente os preços. O aumento da taxa de juros americana levou, ainda, a um aumento da dívida externa. Tais circunstâncias intensificaram os investimentos na exploração de águas profundas e ultra profundas. Na década de 1980, o Brasil conseguiu reduzir a dependência das importaçóes e, na década seguinte, foram encontrados poços de grandes dimensões em águas profundas (SILVA, 2015).

O grande número de privatizaçóes nas décadas de 1980 e 1990 alertou a maior empresa de exploração brasileira para a possível concorrência (VIEIRA FILHO e FISHLOW, 2017). Foi criada em 1997, então, a Agência Nacional do Petróleo, Gás Natural e Biocombustíveis

4 Nas duas crises do petróleo, de 1973 e 1979, o petróleo teve seus preços afetados. Na primeira, a Organização dos Países Exportadores de Petróleo (OPEP) interrompeu a comercializaçáo com os países aliados de Israel, como os EUA, e aumentou em 70\% o preço do barril de petróleo. Na crise de 1979 houve uma queda na oferta resultante de uma diminuição da produção do Irã, que era o segundo maior produtor, e que consequentemente atingiu os preços do produto (PEREIRA, 2008). 
(ANP) a partir do Decreto no 2.455 , de 14 de janeiro de 1998, que já estava prevista na Lei no 9.478 de 6 de agosto de 1997, e tinha por função regulamentar e fiscalizar o mercado petrolífero que havia sido aberto após o fim do monopólio da Petrobras. As atividades realizadas pela empresa continuaram a ser um monopólio da União, mas podiam ser realizadas por empresas privadas por meio de concessão, autorização e contratação sob regime de partilha de produção, sendo tais regimes monitorados pela ANP (ANP, 2017).

A Petrobras investiu massivamente em pesquisa e desenvolvimento para aumentar a produção, destinada tanto para o suprimento interno quanto para exportação. Em 2006 foi encontrada uma grande área de petróleo em águas oceânicas, o Pré-sal, localizado a uma profundidade de 5.000 metros abaixo da superfície do oceano Atlântico (BELTRÃO et al., 2009). Embora seu custo de exploração fosse muito elevado, o óleo encontrado é de melhor qualidade, posto que mais leve quando comparado àquele encontrado nas demais áreas de exploração. Em 2007, a fronteira do Pré-Sal foi estendida, cobrindo uma área de $800 \mathrm{~km}$ de comprimento e $200 \mathrm{~km}$ de largura nas bacias de Campos, Santos e Espírito Santo (VIEIRA FILHO e FISHLOW, 2017).

Os inúmeros desafios encontrados para a exploração de petróleo em águas profundas levaram a Petrobrás a incentivar massivamente o desenvolvimento de pesquisas (P\&D), uma vez que ainda não existiam tecnologias para a perfuração, transporte e armazenamento do petróleo até o transporte para as bases térreas. A Petrobras aumentou sua aplicação de capital em cinco vezes de 2004 a 2010, passando de 9 US\$ bilhóes para 45 US\$ bilhóes, para o desenvolvimento da exploração, simultaneamente a construção de refinarias e aplicação em infraestrutura de transportes (FURTADO, 2013).

A partir de 2010, o país apresentou forte crescimento na produção total de petróleo, saindo da $13^{a}$ posição em 2010 , com uma produção diária de 2 milhóes de barris por dia, para a $10^{\circ}$, em 2020 , com aproximadamente 3 milhóes de barris/dia. O incremento na produção é devido, sobretudo, à exploração do Pré-sal, que teve sua produção ampliada em 60 vezes, saindo de menos de 50 mil barris/dia em 2010 para mais de 2 milhóes em 2020, em que, apesar da pandemia mundial, o país registrou o maior valor da produção nacional, com crescimento de 5,22\% em relação a 2019 (ANP, 2020).

Como pode ser verificado na Figura 1, para o ano de 2020, o Rio de Janeiro foi o estado que mais se sobressaiu sendo responsável por $78 \%$ da produção do petróleo e 59\% do gás natural nacional. Esse valor relativo vem crescendo com o decorrer dos anos, já que em janeiro de 2016 era verificado que o estado respondia por $68 \%$ da produção de petróleo e 46\% na de gás natural (ANP, 2020). 
Figura 1- Produção de Petróleo e gás natural por estado

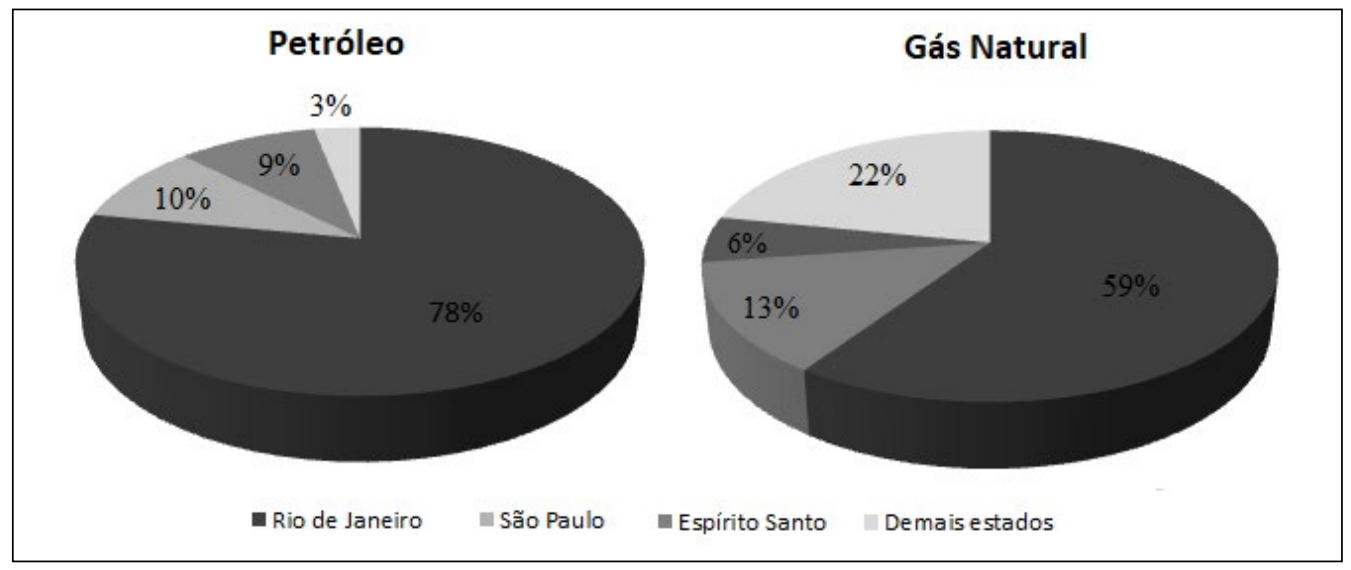

Fonte: Elaboração dos autores com dados da Agência Anual do Petróleo (2020).

De acordo com Silva (2004) e Fernandes (2007), a indústria extrativista no estado do Rio de Janeiro começou a mostrar sua importância na década de 1970 quando a Petrobras descobriu e iniciou a produção na Bacia de Campos, em 1977, no Campo de Enchova, a maior bacia sedimentar brasileira, abrangendo um território de $100.000 \mathrm{~km}^{2}$ na costa dos estados do Rio de Janeiro e Espírito Santo. O notório crescimento do setor na década de 1980 pode ser observado pela mudança significativa na participação das indústrias de transformação e extrativista no PIB do Rio de Janeiro. Enquanto na primeira metade da década a indústria de transformação sofreu uma queda de $10,1 \%$ para $9,5 \%$, a extrativista passou de $1,4 \%$ para $13,3 \%$. Na segunda metade da década, a participaçáo da extrativa sofreu um grande avanço, chegando em $48,5 \%$ do total do estado, ao passo que o setor de transformação permaneceu próximo ao patamar do começo da década.

O título de principal produtor de petróleo e derivados do país dá ao estado o direito sobre alguns pagamentos realizados pelas empresas exploradoras e produtoras respaldadas pela Lei 9.478 de 1997, criada após o fim do monopólio da Petrobras, estabelecendo que as empresas petrolíferas que obtivessem a concessão ou a licença de exploração dos campos brasileiros deveriam realizar o pagamento das participaçóes governamentais aos estados e municípios onde está localizada a exploração (FERNANDES, 2007).

As participações são divididas em quatro modos, que incluem o Bônus de Assinatura (valor pago pelos concessionários no momento da concessão de exploração), os Royalties (remuneração sobre a exploração do petróleo sendo pago mensalmente, calculado com uma alíquota que pode variar de $5 \%$ a $10 \%$ sobre o valor da produção, com referência internacional multiplicado pelo volume de produção), as Participações Especiais (compensações extraordinárias referentes a campos que produzem em grande escala e possuem uma alta rentabilidade e é pago trimestralmente), e o Pagamento pela Ocupação de Área (feita aos proprietários das terras munidas de petróleo durante o período de exploração e produção) (ANP, 2019). 
Em 2020, o estado do Rio de Janeiro recebeu R \$ 4,7 bilhóes em royalties, o que corresponde $74 \%$ do total repassado para todos os estados do país. Para a distribuição municipal, $65 \%$ do total dos royalties ficou com as cidades fluminenses totalizando $\mathrm{R} \$$ 5,1 bilhóes. Entre elas, os maiores valores foram para Maricá, Macaé, Niterói, Saquarema e Campos dos Goytacazes que somados representam aproximadamente 50\% do total.

\subsection{Importância dos leilóes}

Com a flexibilização do monopólio da Petrobras, a Agência Nacional do Petróleo anunciou em dezembro de 1998 o início das rodadas de licitações por regime de concessão para as empresas privadas nacionais e estrangeiras, com o intuito de acelerar a produçáo do óleo nacional e trazer novas tecnologias para o país. No regime de concessão, a responsabilidade, os custos e o risco de exploraçáo são todos da empresa nomeada, assim como o óleo encontrado. A escolha da companhia ou consórcio para a exploração de cada campo é analisada verificando a melhor oferta, isto é, aquela em que a empresa ganha mais pontos quando se leva em conta o valor oferecido do bônus de assinatura e do Programa Exploratório Mínimo (PEM) ${ }^{5}$ que deve seguir as regras do edital (ANP, 2019).

Com a descoberta do Pré-sal, a União elaborou a Lei no 12.351 de 2010 que institui o regime de partilha da produção, na qual a Petrobras é a operadora de todos os blocos de exploração. Através da Lei no 13.365/2016, a Petrobras deixou de ser a empresa única e passou a ser detentora da prioridade inicial, devendo anunciar seu interesse nos blocos do Pré-sal, especificando quais blocos e o motivo da escolha, de modo que a participação total da empresa não seja inferior a 30\%. Após a ação da Petrobras, é realizada uma sessão pública em que as empresas interessadas declaram qual a porcentagem do excedente de óleo será ofertada à União e o direito de exploração é dado àquele que o excedente oferecido for maior (ANP, 2017).

De acordo com a lei supracitada, o Brasil passou a ter legalmente um regime misto, onde os campos offshore e aqueles atribuídos como áreas estratégicas para o governo nacional podem ser operados em regime de partilha ou diretamente pela Petrobras como forma de preservar os bens nacionais, sendo a escolha determinada pelo Conselho Nacional de Política Energética (CNPE). Os demais campos de exploraçáo são licitados em regime de concessáo (ANP, 2019). Os valores arrecadados nos leilóes são destinados a União e a ANP. O Bônus de Assinatura faz parte da arrecadação governamental, já o Programa Exploratório Mínimo e o Programa de Trabalho Inicial são recebidos pela ANP como uma garantia financeira do cumprimento das atividades determinadas para o período de exploração (ANP, 2019).

Desde 1999 já foram realizados 19 leilóes sob o regime de concessão, sendo 15 em blocos exploratórios e 4 em campos maduros. Os blocos de exploração geraram uma renda de aproximadamente $\mathrm{R} \$ 34,5$ bilhóes em bônus de assinatura e PEM, enquanto os resultados dos campos maduros, ao serem somados os bônus e o Programa de Trabalho Inicial (PTI), criaram um montante de $\mathrm{R} \$ 113,5$ milhóes. Sob o regime de partilha de produção houve 5 rodadas de licitaçóes do Pré-sal, o que produziu uma arrecadação total

5 Garantia financeira do possível náo cumprimento das atividades no período de exploração. 
de R \$ 34,2 bilhōes (em bônus de assinatura e PEM). Há um planejamento de duas rodadas sob regime de concessão e duas sob regime de partilha que irão acontecer em 2021 (ANP, 2020).

Segundo Rodriguez et al. (2008), o modelo adotado de licitaçóes tem por finalidade a maximização das receitas governamentais, o estímulo a competitividade no setor através de uma maior alocaçáo de recursos e o aumento das informaçóes no âmbito produtivo, geológico e geofísico. Os autores enfatizam o sucesso dos leilóes, uma vez que os valores arrecadados são satisfatórios e a diversificação das concessionárias de pequeno, médio e grande porte é alta. De acordo com a ANP (2020), já participaram dos leilōes mais de cem instituiçóes, tanto nacionais quanto estrangeiras.

O modo como é realizada a proposta dos leilóes ocasiona um aumento de renda que pode gerar investimentos de forma direta e indireta para o país. Para Bresser-Pereira (2007), o desenvolvimento econômico pautado no aumento de produtividade e de salários está estritamente ligado ao ato de investir juntamente com a participação do progresso técnico. Alguns autores salientam a importância do investimento em algumas áreas, como em infraestrutura, uma vez que o desenvolvimento da industrialização só é possível quando se tem uma indústria de base (SILVA, 2015).

Os impactos no mercado petrolífero também influenciam a criação direta e indireta de empregos, o desenvolvimento social e o estímulo aos avanços tecnológicos, além da transferência de renda para todas as esferas públicas (PACHECO, 2003). Segundo Da Cruz (2018), em 2002 a Petrobras detinha 6.900 empregos diretos e 28.000 empregos terceirizados, totalizando 34.900 postos de trabalho. As localidades afetadas diretamente pelo setor demandam uma mão de obra direta mais qualificada, o que gerou migraçóes de pessoal capacitado para os municípios centrais. Em contrapartida, a população com um menor nível de instrução oferta seus serviços de maneira indireta, de modo temporário e nas localidades mais próximas das regiôes principais.

Oliveira et al. (2011) também analisaram os impactos do setor e concluíram que o setor petrolífero gera grandes efeitos multiplicadores de modo agregado e não abrange todos os setores. Os autores aplicaram um choque de $100 \%$ nos setores petrolíferos em 2004, tendo como resultado um aumento do nível de empregos, que gerou um aumento da renda e do consumo das famílias no curto prazo, uma vez que os setores mais afetados são os de bens intensivos em capital e estes não possuem muitos efeitos multiplicadores. Os setores mais incentivados em replicar o investimento inicial foram aqueles voltados para a estrutura produtiva, isto é, setores de máquinas e equipamentos, siderúrgicas, construçáo civil e equipamentos eletrônicos.

Em seu trabalho, Piquet (2012) concluiu não haver impactos maiores nos setores da própria rede do petróleo e acrescentou que este campo demanda constantemente mão de obra qualificada e especialização/inovação das empresas nacionais, uma vez que os produtos de alto valor agregado ainda são importados. $\mathrm{O}$ autor expôs que quando se analisa o setor petrolífero pela ótica nacional, ele é o mais importante e avançado em áreas tecnológicas e estratégicas, no entanto, alerta que a baixa eficiência na coordenação e distribuição dos 
recursos, podendo manter o país em seu nível subdesenvolvido devido à doença holandesa ${ }^{6}$. O autor cita países como a Venezuela e a Nigéria que detém altas rendas com as exportaçóes do combustível, entretanto, não utilizam este retorno para investir no bem-estar social através da diversificação de atividades produtivas no longo prazo.

Outra crítica envolvendo o setor de petróleo reside nos impactos ambientais e na ineficiência do governo com a utilização dos recursos recebidos. Bozelli et al. (2008) chegaram à conclusão de que o prejuízo ambiental causado pela exploração da bacia de campos não pode ser analisado separadamente da urbanização das regiōes afetadas, uma vez que a poluiçẫo dentre outras externalidades negativas estáo ligadas tanto com acidentes de exploraçáo como com a falta de atenção do governo com as condiçóes básicas de saneamento.

\section{Metodologia e base de dados}

\subsection{Metodologia}

O sistema de insumo-produto, proposto por Leontief (1941), é uma ampliação da teoria neoclássica de interdependência geral para resolver o problema de assimetria da distribuição do fluxo circular de renda entre as classes. Logo, o modelo observa o mundo como um sistema simples e analisa as relaçôes de interdependência dos setores da economia (GUILHOTO, 2011).

A matriz de insumo-produto funciona como uma fotografia da realidade e é dada por todas as transaçóes macroeconômicas que acontecem entre os setores da economia. Nela são registradas as entradas de insumos de bens e serviços entre os setores da economia e a saída dos bens finais consumidos pelas famílias, pelo governo, demandada pelos investimentos e exportadas (NOBREGA et al, 2014). O fluxo de bens entre os setores é o que proporciona uma visão mais ampla da economia, pois permite saber quais setores são os compradores e os vendedores de produtos (MILLER e BLAIR, 2009).

Considerando o modelo de insumo-produto, este pode ser representado de forma matricial pela Equação (1):

$$
(I-A) X=Y
$$

Onde: $I$ representa uma matriz identidade $n \mathrm{x} n$

$A$ representa a matriz de coeficientes técnicos ou de coeficientes diretos

$X$ representa o vetor do valor bruto da produção

$Y$ representa o vetor de demanda final

Por meio da matriz de coeficientes técnicos se conhece as relaçóes diretas entre os setores, i.e., é possível calcular os efeitos diretos de um aumento da demanda final.

6 A doença holandesa também caraterizada como Maldição dos Recursos Naturais (MRN) se deu em 1970 na Holanda quando um aumento das arrecadaçôes ligadas à exploração de gás natural teve em contrapartida um processo de desindustrialização do país. Sendo assim, a MRN se dá pelo excesso de atenção aos setores primários em detrimento dos manufatureiros de modo a prejudicar o crescimento eficiente da regiáo através de concentraçáo de renda e corrupçáo (SILVA, 2015). 
Entretanto, para encontrar tanto os efeitos diretos como os indiretos de um aumento da demanda final, é necessário calcular a matriz inversa de Leontief. Da Equação (1) obtém-se:

$$
\mathrm{X}=\mathrm{BY}
$$

Onde: $\mathrm{B}=(1-\mathrm{A})^{-1}$ é a inversa de Leontief ou matriz de efeitos diretos e indiretos.

A matriz de insumo- produto pode também ser uma inter-regional conforme aplicação feita por Isard (1951). No modelo podem ser observadas as relaçóes diretas e indiretas entre regióes. O problema desse tipo de análise reside na alta necessidade da coleta de dados, dificultando a construção da matriz (GUILHOTO et al., 2010). Nesse caso, em um modelo hipotético de duas regióes $L$ e $M$, o fluxo monetário pode ser expresso de forma matricial de acordo com a Equação (3)

$$
Z=\left[\begin{array}{ll}
Z^{L L} & Z^{L M} \\
Z^{M L} & Z^{M M}
\end{array}\right]
$$

Onde:

$Z_{i j}^{L M}$ : é o fluxo monetário do setor $i \mathrm{da}$ região $\mathrm{L}$, para o setor $j$ da região $\mathrm{M}$.

$Z_{i j}^{M L}$ : é o fluxo monetário do setor $i$ da região $\mathrm{M}$, para o setor $j$ da região $\mathrm{L}$.

$Z^{L L}$ e $Z^{M M}$ são os fluxos monetários intrarregionais.

Da mesma forma que foi calculada a matriz inversa de Leontief na Equaçáo (2), encontram-se os efeitos diretos e indiretos de um aumento da demanda final de determinado setor $i$ em uma região $j$.

\subsubsection{Multiplicadores}

De acordo com Miller e Blair (2009), através do modelo básico pode-se estimar o impacto que uma variaçáo na demanda final gera sobre os componentes macroeconômicos como, por exemplo, empregos, salários, produção total, importaçóes, valor adicionado, renda, dentre outros. Tal impacto, também considerado como multiplicadores, opera em cada setor da economia mostrando os efeitos diretos e indiretos.

Para tanto, é necessário dividir, para cada setor, o valor de cada indicador pela produçáa total de cada setor:

$$
v_{i}=\frac{v_{i}}{x_{i}}
$$

Obtemos então os multiplicadores simples que mostram os impactos diretos e indiretos para cada unidade monetária produzida para a demanda final através do somatório da multiplicação de cada elemento da matriz Leontief $(b i j)$ com os coeficientes dos indicadores macroeconômicos.

$$
G V_{J}=\sum_{i=1}^{n} b_{i j} v_{i}
$$


O multiplicador tipo I é dado pela divisão do multiplicador simples pelos coeficientes de cada indicador e mostram qual a quantidade de cada elemento é impactada direta e indiretamente por uma mudança direta em algum indicador específico:

$$
M V_{i}=\frac{G V_{i}}{v_{i}}
$$

\subsection{2 Índices de Hirschman-Rasmussen e suas Dispersóes}

Os Índices de Hirschman (1958) e Rasmussen (1956) complementam a análise dos setores e determinam quais destes tem maior encadeamento na economia. São calculados os índices de ligaçóes para trás que representam quanto um setor demanda de insumos da economia e os índices de ligação para frente que mostram quanto um setor tem seus insumos demandados pelos outros setores. Quando o valor desses índices supera uma unidade significa que são setores acima da média e chaves para o crescimento da economia, sendo setores com grandes ligaçóes com o restante da economia. Com a Equação (7) obtémse o índice de ligação para trás e a Equação (8), o índice de ligação para frente.

$$
\begin{aligned}
& U_{j}=\frac{B_{* j} / n}{B^{*}} \\
& U_{j}=\frac{B_{i *} / n}{B^{*}}
\end{aligned}
$$

Para complementar os índices de Hirschman-Rasmussen, conforme Bulmer-Thomas (1982), pode-se calcular a dispersão dos índices, pois os mesmos possibilitam interpretar como um impacto setorial distribui-se para os demais setores. Quando há um baixo valor na dispersão do índice de ligação para trás, tem-se que um impacto de uma variação na produção de um determinado setor tende a estimular os demais setores de maneira uniforme. Se o valor for alto, significa que o impacto irá se concentrar em poucos setores, ou seja, será heterogêneo. A expressão (9) apresenta o cálculo da dispersão do índice de ligação para trás.

A dispersão para frente mostra se determinado setor, conforme Casimiro Filho (2002), terá seus insumos demandados pelos demais setores de forma homogênea ou heterogênea. Quanto maior o valor encontrado, mais concentrado será a demanda de seus insumos pelos demais setores. Caso contrário, ou seja, para baixos valores, o setor é demandado pelos demais de maneira uniforme. A expressão (10) traz a dispersão do índice de ligação para frente.

$$
V_{j}=\frac{\sqrt{\frac{\sum_{i}^{n}\left(b_{i j}-\frac{B_{* j}}{n}\right)^{2}}{n-1}}}{B_{* j / n}}
$$




$$
V_{i}=\frac{\sqrt{\frac{\sum_{i}^{j}\left(b_{i j}-\frac{B_{i j}}{n}\right)^{2}}{n-1}}}{B_{i * / n}}
$$

\section{2 Base de dados}

Para identificar o impacto do Pré-Sal sobre a economia fluminense foram utilizadas duas matrizes inter-regionais das regióes Rio de Janeiro (RJ) e Restante do Brasil (RBR). A primeira matriz foi construída em 2008 pelo Núcleo de Economia Regional e Urbana da Universidade de São Paulo (NEREUS) a partir dos dados de 2000 das Contas Nacionais e das Contas Regionais corrigidos para 2008. A matriz possui 26 setores da regiáo do estado do Rio de Janeiro e os mesmos 26 setores da regiáo Restante do Brasil, agregação dos demais estados brasileiros.

A segunda matriz foi desenvolvida por Haddad et al. (2017) para o ano de 2011 e possui os 26 estados da federaçáo e o distrito federal. A matriz foi estimada utilizando o método Interregional Input-Output Adjustment System (IIOAS) que pode ser construído para países que possuam um sistema de informaçôes setoriais regionalizadas e que publiquem suas tabelas de usos e recursos (TRUs). Essa matriz, por sua vez, apresenta um nível maior de desagregaçáo das atividades, estando dividida em 52 setores em cada regiâo.

A matriz construída por Haddad et al. (2017) foi agregada em duas regiôes: Rio de Janeiro e o Restante do Brasil. Como um dos propósitos desse trabalho é elucidar a estrutura setorial fluminense e verificar a importância do setor petrolífero, foram comparadas as duas matrizes. Porém, para que isso pudesse ser realizado, houve a necessidade de compatibilização dos setores que pode ser acompanhado na Tabela A1 que está disponível no Anexo.

O setor petrolífero está mais desagregado na matriz 2011, sendo representado por dois setores: i) Extração de petróleo e gás, inclusive as atividades de apoio e ii) Refino de petróleo e coquerias. Na matriz de 2008 há apenas o setor Refino de petróleo e coquerias representando o setor petrolífero. Dessa forma, na impossibilidade dos dados em manter o nível mais desagregado da atividade, foi necessário agregar os dois setores de 2011 para representar o setor de Petróleo.

O procedimento também foi aplicado em outros setores, como o setor referente à Saúde, que na matriz de 2008 é formado por apenas um setor (Saúde mercantil e Saúde pública), enquanto em 2011 se apresenta decomposto em dois setores: i) Saúde pública e ii) Saúde mercantil. Entretanto, em alguns casos não foi necessário usar esse procedimento pelo fato de o setor estar presente da mesma forma nas duas matrizes, como é o caso do setor Construção e do setor Administração pública, defesa e seguridade social.

\section{Resultados}

Esta seção está dividida em duas partes, tendo na primeira uma análise em separado das matrizes da regiâo do Rio de Janeiro com 26 setores referentes aos anos de 2008 e 2011. 
Na segunda parte é feito um estudo da matriz inter-regional de 2011, que engloba as regióes Restante do Brasil e Rio de Janeiro, através da análise da interação dessas regióes por meio do multiplicador do valor adicionado.

\subsection{Estrutura setorial da economia fluminense do ano de 2008 e 2011.}

Para as matrizes do estado do Rio de Janeiro foram calculados os índices de Rasmussen-Hirschman que, como salientado na seção anterior, mostram os setores que mais influenciam a economia através dos índices de ligação para frente e para trás, os quais trazem os setores que mais ofertam e os que mais demandam insumos. Foram encontradas também as dispersōes destes índices, isto é, a forma como é distribuída entre os setores os insumos demandados e ofertados, também sendo identificados os setores chave. Além desses indicadores, foi calculado o multiplicador de produçáo que demonstra o efeito sobre a produção de um choque na demanda final.

No primeiro recorte de tempo, que pode ser visualizado na Tabela 1, 11 setores se destacaram quanto à necessidade de compra de insumos dos demais setores para a realização de suas atividades fins, ou seja, aqueles acima de uma unidade, portanto, acima da média. Os maiores valores foram Refino de Petróleo (7) e Eletricidade e gás (16).

Os resultados permitem observar que o setor petrolífero é o principal setor que estimulou a economia fluminense em 2008 através da sua demanda, o que vem ao encontro do estudo de Piquet (2012), que o identificou como o mais estratégico em âmbito nacional. O segundo setor que se destacou pode ter seu resultado ligado à criação da Lei no 11.445 de 2007, a Lei do Saneamento, em que foi instituído a universalização do acesso. Esta nova condição gerou uma necessidade de aumento da infraestrutura e da aquisição de novos insumos para a construção dos parques de distribuição, coleta, dentre outros, em prol de atender a todos os consumidores.

Tabela 1 - Índices de Ligação para frente e para trás e suas Dispersões para 2008

\begin{tabular}{l|cccc|cccc}
\hline \multirow{2}{*}{\multicolumn{1}{c|}{ Setores }} & \multicolumn{7}{c}{ 2008 } \\
\cline { 2 - 9 } & \multicolumn{6}{c}{ Para trás } & \multicolumn{4}{c}{ Para Frente } \\
\cline { 2 - 9 } & Uj & Ordem & Dispersáo & Ordem & Ui & Ordem & Dispersáo Ordem \\
\hline 1 Agricultura & 0,97 & 16 & 3,85 & 14 & 0,76 & 23 & 4,93 & 7 \\
2 Pecuária e pesca & 0,99 & 12 & 3,80 & 18 & 0,77 & 21 & 4,88 & 8 \\
3 Mineraçáo & 0,97 & 14 & 3,87 & 13 & 1,39 & 3 & 2,73 & 24 \\
4 Alimentos e bebidas & 1,01 & 9 & 3,80 & 19 & 0,96 & 10 & 4,00 & 17 \\
5 Têxtil e calçados & 0,92 & 21 & 4,16 & 5 & 0,77 & 22 & 4,99 & 5 \\
6 Madeira & 0,91 & 23 & 4,19 & 3 & 0,87 & 11 & 4,37 & 15 \\
7 Petróleo & 1,32 & 1 & 3,29 & 26 & 1,17 & 8 & 3,71 & 18 \\
8 Químicos & 1,00 & 11 & 3,96 & 12 & 1,24 & 6 & 3,22 & 22 \\
9 Artigos de borracha & 1,11 & 3 & 3,37 & 25 & 0,85 & 12 & 4,46 & 13 \\
10 Cimento & 1,10 & 5 & 3,53 & 23 & 0,82 & 15 & 4,75 & 10 \\
11 Metalurgia & 1,01 & 10 & 4,09 & 8 & 1,21 & 7 & 3,39 & 21
\end{tabular}




\begin{tabular}{|c|c|c|c|c|c|c|c|c|}
\hline \multirow{3}{*}{ Setores } & \multicolumn{8}{|c|}{2008} \\
\hline & \multicolumn{4}{|c|}{ Para trás } & \multicolumn{4}{|c|}{ Para Frente } \\
\hline & $\mathbf{U j}$ & Ordem & Dispersáo & Ordem & Ui & Ordem & Dispersão & Ordem \\
\hline 12 Equipamentos & 1,07 & 7 & 3,50 & 24 & 0,78 & 18 & 4,83 & 9 \\
\hline $\begin{array}{l}13 \text { Material elétrico e } \\
\text { eletrônicos }\end{array}$ & 1,11 & 4 & 3,53 & 22 & 0,78 & 17 & 5,01 & 3 \\
\hline $\begin{array}{l}14 \text { Material de } \\
\text { transporte }\end{array}$ & 1,08 & 6 & 3,64 & 21 & 0,79 & 16 & 4,95 & 6 \\
\hline 15 Indústrias diversas & 0,98 & 13 & 3,74 & 20 & 0,74 & 24 & 5,01 & 4 \\
\hline 16 Eletricidade e gás & 1,18 & 2 & 3,99 & 10 & 1,32 & 5 & 3,55 & 19 \\
\hline 17 Construção & 0,90 & 24 & 4,11 & 7 & 0,83 & 14 & 4,46 & 14 \\
\hline 18 Comércio & 0,92 & 20 & 4,08 & 9 & 1,53 & 2 & 2,49 & 25 \\
\hline 19 Transporte & 1,04 & 8 & 3,80 & 17 & 1,36 & 4 & 2,92 & 23 \\
\hline 20 Serviços privados & 0,96 & 18 & 4,50 & 2 & 2,06 & 1 & 2,17 & 26 \\
\hline 21 Financeira e seguros & 0,97 & 15 & 4,18 & 4 & 1,15 & 9 & 3,55 & 20 \\
\hline 22 Imobiliários & 0,76 & 26 & 4,82 & 1 & 0,84 & 13 & 4,35 & 16 \\
\hline 23 Alojamento & 0,96 & 17 & 3,80 & 16 & 0,78 & 19 & 4,72 & 12 \\
\hline 24 Educação & 0,88 & 25 & 4,16 & 6 & 0,73 & 26 & 5,02 & 2 \\
\hline 25 Saúde & 0,95 & 19 & 3,84 & 15 & 0,73 & 25 & 5,03 & 1 \\
\hline 26 Administração & 0,92 & 22 & 3,99 & 11 & 0,78 & 20 & 4,73 & 11 \\
\hline
\end{tabular}

Fonte: Elaboração dos autores.

Nota: Em negrito estão os setores chave da economia.

Com relação à dispersão para trás, o setor de artigos petrolíferos assumiu o menor valor, demonstrando que é o setor que compra de maneira mais uniforme comparado aos demais. Assim, como o setor de eletricidade, o setor petrolífero também sofreu mudanças em 2007 como já destacado na seção 2. Com a descoberta do Pré-sal, os investimentos foram intensificados, o que pode explicar o alto grau de compras e a diversificaçáo destas, uma vez que a empresa que tinha permissão de exploraçáo precisava construir novas tecnologias de perfuraçẫo, transporte etc.

Quanto aos setores que mais vendem, nove se destacaram, sendo o de Serviços Privados (20) aquele com maior valor calculado, seguido por Comércio (18), Mineração (3) e Transporte, armazenagem e correio (19). Refino de Petróleo, Coque e Álcool obteve o oitavo maior valor entre os 26 setores analisados. Cabe destacar que o setor petrolífero apresentou maior capacidade de demandar insumos dos demais setores comparados à capacidade de ofertar insumos na economia. Todavia, isso não implica que o setor tem baixa capacidade de ofertar insumos, mas sim que ele tem um potencial maior de desencadear efeitos spilover na economia.

O setor Serviços Privados (20), que apresentou o maior valor do índice de ligação para frente, tem seu comportamento explicado por Guilhoto et al. (2010), que concluem que o desenvolvimento de setores manufatureiros tende a depender do desenvolvimento de setores primários, já que o primeiro necessita de insumos para a produção de seus bens 
finais. Esse setor também costuma apresentar problemas de infraestrutura, diferentemente do que ocorre com setores de serviços e comércio, intensivos em mão de obra, o que diminui a dependência dos demais setores.

$\mathrm{Na}$ dispersão dos índices de ligação para frente, o setor referente ao petróleo ocupou a $18^{\text {a }}$ posição, o que significa que vende de forma mais uniforme comparado aos demais. Serviços Privados e Comércio foram os setores que mais vendem para os demais setores de modo mais uniforme.

A partir dos resultados encontrados nos índices de ligação para frente e para trás, conforme a seção 3, pode-se encontrar os setores chave, isto é, aqueles que assumiram papéis importantes no encadeamento da economia do Rio de Janeiro em 2008. Foram cinco setores: Refino de petróleo (7), Outros produtos químicos (8), Metalurgia (11), Eletricidade e gás (16) e Transporte (19). Esses setores estáo destacados na Tabela 1 e significa que eles possuem simultaneamente valores acima da média nos índices de ligação para frente e para trás, portanto, têm capacidade de comprar e vender insumos acima da média quando comparado com os demais.

O setor petrolífero, como já destacado, está dentre os setores que influenciam a economia, uma vez que seu produto assume um caráter extremamente importante como matéria prima, insumo intermediário e bem final de vários mercados. Guilhoto et al. (2010), concluíram que setores base são tecnológica e economicamente essenciais para o desenvolvimento econômico.

Takasago, Mollo e Guilhoto (2017) salientam da importância em priorizar investimentos em setores industriais, pois consideram que esses têm maior capacidade de desenvolver a economia com o crescimento da produtividade, em especial os setores de tecnologia mais sofisticada, como o caso do setor de Refino de petróleo e gás natural. Em seu estudo, os autores encontraram, em matrizes de insumo-produto contendo 56 setores, que o setor Refino de petróleo e coque é setor-chave da economia brasileira nos anos de 2000, 2004 e 2008, enquanto que o setor Petróleo e gás natural se mostrou chave para os anos de 2004 e 2008. Para o ano de 2000, apesar de não ser considerado como setor-chave, o mesmo se mostrou acima da média na ótica das vendas.

Além do cenário nacional, o setor petrolífero também se destacou em outros estados como pode ser verificado em Leivas e Feijó (2014) com uma matriz de insumo-produto do Rio Grande do Sul do ano de 2003. Os autores identificaram entre os 26 setores produtivos, que o Refino de petróleo é setor-chave da economia gaúcha, sendo encontrado o segundo maior valor no índice de ligação para frente, diferentemente do caso fluminense que, como foi verificado nesse estudo, apresentou maior valor no lado da demanda.

Em outros estados, os setores relacionados ao petróleo também se destacaram. Para a Bahia, Perobelli et al. (2015), com uma matriz insumo-produto de 2009 com 27 atividades, encontraram o setor Produtos do refino de petróleo e coque chave para o crescimento da economia baiana. Os autores destacam que politicas a nível estadual contribuíram na modernização da estrutura produtiva da região. Da mesma forma, em Pernambuco, com uma matriz de 2005, a Agência Estadual de Planejamento e Pesquisas de Pernambuco 
(2011) identificou como sendo setor chave da economia a atividade de Refino de petróleo e coque.

Para o estado capixaba, apesar de ser um dos maiores produtores de petróleo do Brasil, os setores de Extração de petróleo e gás e o de Refino de petróleo não podem ser considerados chaves, conforme Instituto Jones dos Santos Neves (2020). Para o estudo, foi construída uma matriz estadual de insumo-produto do ano de 2015 com 35 atividades, na qual identificaram três setores-chaves. Apesar de não serem chaves na economia do Espírito Santo, tanto o setor de Extração, quanto o de Refino mostraram-se elevados valores nos índices de ligação para frente, portanto, se destacam por terem seus insumos demandados pelos outros setores acima da média.

Para o ano de 2011, os resultados podem ser visualizados na Tabela 2. Dezessete setores se mostraram influentes na economia por meio de suas compras. Aqueles que assumiram valores mais altos foram Eletricidade e gás (16), Mineração (3), Cimento (10) e Serviços privados (20). O setor de Refino de petróleo (7) ocupou a $11^{\text {a }}$ colocação dentre os mais importantes. No ano de 2008, como destacado anteriormente, eram onze os setores que influenciavam a economia acima da média. Desta forma, para 2011, a economia apresentou uma maior diversidade dos setores em relação à compra de insumos.

Em relação à dispersão para trás, os valores não apresentaram grande variações entre 2008 e 2011. Em 2008, os setores mais homogêneos para realização de compras foram os setores Refino de Petróleo e Artigos de borracha, ao passo que, em 2011, destacaram-se Mineração e Cimento.

O setor petrolífero teve uma queda de um período para o outro tanto na influência para trás, quanto na distribuição dela. Ele passou do $1^{\mathrm{a}}$ para o $11^{\mathrm{a}}$ lugar em relação ao nível de compras, demonstrando que o setor diminuiu seu poder de encadeamento por meio das provisões, e da $26^{\mathrm{a}}$ para a $8^{\mathrm{a}}$ posição no que diz respeito à uniformidade desse consumo, tal que as compras se tornaram mais heterogêneo pelos setores da economia.

De modo geral, a diminuição das compras do setor pode estar ligada ao novo marco legal definido pela Lei no 12.351 de 2010, que instituiu a Petrobras como única empresa detentora da exploração e produção nas áreas do Pré-sal. No novo regime de partilha de produção, a empresa ainda deve assumir todos os riscos e custos encontrados durante o processo de exploração, gerando maiores incertezas e desequilíbrios no setor.

Além disso, pode-se atribuir o resultado aos reflexos que a crise financeira mundial provocou no país, posto que promoveu mudanças estruturais na economia e, aliada às incertezas no cenário mundial, resultou em uma retração de novos investimentos, gerando a restrição de novas compras. O setor petrolífero, em especial, ainda assumiu perdas financeiras devido ao controle de preços feito pelo governo federal. Analisando especificamente os setores impactados pela diminuição de investimentos da cadeia do petróleo temos, segundo Oliveira et al. (2011), produtos da construção civil, equipamentos eletrônicos e máquinas e equipamentos. Para o setor de construção civil, por exemplo, em 2011 houve um o crescimento do PIB setorial de apenas 3,6\%, enquanto o ano anterior registrou $11,6 \%$ e, em 2008, 7,9\% (DIEESE, 2013). 
O índice de ligação para frente de 2011 apresentou oito setores acima da média, sendo eles: Serviços Privados (20), Comércio (18), Transporte (19), Eletricidade e gás (16), Intermediação Financeira (21), Refino de Petróleo (7), Construção (17) e Outros produtos químicos (8). Esse índice não sofreu grandes mudanças em relação à quantidade de setores, partindo de nove para oito, de 2008 para 2011. O setor de Serviços Privados foi o principal destaque em 2011 e o setor de Comércios se manteve na segunda colocação.

Tabela 2 - Índices de Ligação para frente e para trás e suas Dispersões para 2011

\begin{tabular}{|c|c|c|c|c|c|c|c|c|}
\hline \multirow{3}{*}{ Setores } & \multicolumn{8}{|c|}{2011} \\
\hline & \multicolumn{4}{|c|}{ Para trás } & \multicolumn{4}{|c|}{ Para Frente } \\
\hline & $\mathbf{U j}$ & Ordem & Dispersão & Ordem & Ui & Ordem & Dispersáo & Ordem \\
\hline 1 Agricultura & 0,84 & 25 & 4,57 & 2 & 0,77 & 24 & 4,99 & 5 \\
\hline 2 Pecuária e pesca & 0,89 & 24 & 4,34 & 4 & 0,77 & 25 & 5,02 & 4 \\
\hline 3 Mineração & 1,10 & 2 & 3,48 & 26 & 0,79 & 19 & 4,89 & 10 \\
\hline 4 Alimentos e bebidas & 1,05 & 7 & 3,72 & 24 & 0,82 & 14 & 4,78 & 12 \\
\hline 5 Têxtil e calçados & 0,93 & 21 & 4,23 & 7 & 0,78 & 22 & 5,04 & 3 \\
\hline 6 Madeira & 1,00 & 15 & 3,91 & 17 & 0,80 & 17 & 4,90 & 9 \\
\hline 7 Petróleo & 1,03 & 11 & 4,23 & 8 & 1,12 & 6 & 3,89 & 21 \\
\hline 8 Químicos & 1,09 & 5 & 3,77 & 22 & 1,01 & 8 & 4,08 & 17 \\
\hline 9 Artigos de borracha & 1,03 & 10 & 3,80 & 21 & 0,81 & 15 & 4,82 & 11 \\
\hline 10 Cimento & 1,10 & 3 & 3,64 & 25 & 0,97 & 10 & 4,11 & 16 \\
\hline 11 Metalurgia & 1,04 & 9 & 3,73 & 23 & 0,78 & 21 & 4,98 & 7 \\
\hline 12 Equipamentos & 0,97 & 18 & 4,00 & 15 & 0,78 & 20 & 4,99 & 6 \\
\hline $\begin{array}{l}13 \text { Material elétrico e } \\
\text { eletrônicos }\end{array}$ & 1,00 & 16 & 3,85 & 20 & 0,77 & 26 & 5,04 & 2 \\
\hline $\begin{array}{l}14 \text { Material de } \\
\text { transporte }\end{array}$ & 1,01 & 12 & 3,88 & 19 & 0,84 & 13 & 4,69 & 14 \\
\hline 15 Indústrias diversas & 0,91 & 23 & 4,26 & 5 & 0,97 & 9 & 3,97 & 19 \\
\hline 16 Eletricidade e gás & 1,11 & 1 & 4,24 & 6 & 1,32 & 4 & 3,57 & 23 \\
\hline 17 Construçãoo & 1,01 & 14 & 4,15 & 10 & 1,07 & 7 & 3,92 & 20 \\
\hline 18 Comércio & 1,00 & 17 & 4,05 & 12 & 1,83 & 2 & 2,26 & 25 \\
\hline 19 Transporte & 1,05 & 8 & 4,06 & 11 & 1,45 & 3 & 2,95 & 24 \\
\hline 20 Serviços privados & 1,10 & 4 & 4,36 & 3 & 2,26 & 1 & 2,18 & 26 \\
\hline 21 Financeira e seguros & 1,07 & 6 & 3,91 & 18 & 1,12 & 5 & 3,74 & 22 \\
\hline 22 Imobiliários & 0,83 & 26 & 4,67 & 1 & 0,96 & 11 & 4,05 & 18 \\
\hline 23 Alojamento & 0,96 & 19 & 4,01 & 14 & 0,84 & 12 & 4,57 & 15 \\
\hline 24 Educação & 0,93 & 22 & 4,15 & 9 & 0,78 & 23 & 4,94 & 8 \\
\hline 25 Saúde & 1,01 & 13 & 3,98 & 16 & 0,79 & 18 & 5,07 & 1 \\
\hline 26 Administração & 0,95 & 20 & 4,05 & 13 & 0,81 & 16 & 4,75 & 13 \\
\hline
\end{tabular}

Fonte: Elaboração dos autores.

Nota: Em negrito estão os setores chave da economia. 
Em relação à dispersão do índice dos que mais vendem, os setores Serviços Privados (20) e Comércio (18) permanecem como aqueles que distribuem a oferta de modo mais uniforme. Quanto ao setor petrolífero, ocupou a $21^{\text {a }}$ posição, também ofertando seus produtos de modo relativamente uniforme.

O setor petrolífero apresentou pequenas oscilações, passando da $8^{\mathrm{a}}$ posição para $6^{\mathrm{a}}$, no quesito oferta, e da $18^{a}$ para $21^{\text {a }}$, na dispersão, isto é, além de aumentar a capacidade de oferta, isso ocorrera de modo uniforme. Em 2008, o setor se destacava mais por sua capacidade de compras, já em 2011 a capacidade de vendas se sobressaiu.

Os resultados apontam que o setor passou por uma transformação, deixando de ser o principal comprador e assumiu destaque na oferta de insumos. Essa mudança pode estar ligada aos vultuosos investimentos feitos em $\mathrm{P} \& \mathrm{D}$ e em novas tecnologias para extração após a descoberta do Pré-sal em 2007.

O aumento da oferta e das vendas em 2011 é consequência do aumento da produção, e impacta diretamente na quantidade de Participaçóes Governamentais recebidas pelos estados, em especial o Rio de Janeiro. Todavia, a falta de fiscalização no recebimento deste capital pode, conforme verificado Postali (2012) e Piquet (2012), gerar um aumento das ineficiências nas prefeituras causado pela dependência do recebimento do capital e seu possível mal investimento, podendo gerar a Maldição dos Recursos Naturais. Além disso, os problemas ambientais também podem se agravar caso o devido cuidado não seja tomado mediante o aumento das explorações.

Analisando aqueles setores que geram encadeamentos tanto pelo lado da oferta, quanto pelo lado da demanda, temos, em 2011, Refino de petróleo (7), Outros produtos químicos (8), Eletricidade e gás (16), Construção (17), Comércio (18), Transporte (19), Serviços privados (20) e Intermediação financeira (21). Comparando com a economia de 2008, observam-se alguns setores em comum que são: Refino de petróleo (7), Outros produtos químicos (8), Eletricidade e gás (16), Transporte (19). A diferenciação dos setores chave para os dois anos está nos setores: Metalurgia (11) em 2008 e em 2011, Construção (17), Comércio (18), Serviços Privados (20) e Intermediação Financeira (21) também foram setores que se destacaram em relação ao encadeamento para frente e para trás.

\subsection{Multiplicador de produção}

Esta subseção trata do multiplicador de produção que, como destacado na seção metodológica, mostra o aumento no valor bruto da produção na economia quando há variação de uma unidade monetária de forma exógena na demanda final de um dado setor. Salienta-se que essa demanda final é composta de consumo das famílias, investimentos, gastos do governo e exportaçóes. Os resultados calculados estão dispostos na Tabela 3. 
Tabela 3 - Multiplicador de Produção dos anos 2008 e 2011

\begin{tabular}{|c|c|c|c|c|}
\hline \multicolumn{5}{|c|}{ Multiplicador de Produçáo } \\
\hline \multirow{2}{*}{ Setores } & \multicolumn{2}{|c|}{2008} & \multicolumn{2}{|c|}{2011} \\
\hline & Valor & Ordem & Valor & Ordem \\
\hline 1 Agricultura & 1,35 & 16 & 1,12 & 25 \\
\hline 2 Pecuária e pesca & 1,38 & 12 & 1,17 & 24 \\
\hline 3 Mineração & 1,36 & 14 & 1,46 & 2 \\
\hline 4 Alimentos e bebidas & 1,41 & 9 & 1,39 & 7 \\
\hline 5 Têxtil e calçados & 1,28 & 21 & 1,23 & 21 \\
\hline 6 Madeira & 1,26 & 23 & 1,33 & 15 \\
\hline 7 Petróleo & 1,83 & 1 & 1,36 & 11 \\
\hline 8 Químicos & 1,40 & 11 & 1,45 & 5 \\
\hline 9 Artigos de borracha & 1,55 & 3 & 1,36 & 10 \\
\hline 10 Cimento & 1,53 & 5 & 1,46 & 3 \\
\hline 11 Metalurgia & 1,40 & 10 & 1,38 & 9 \\
\hline 12 Equipamentos & 1,49 & 7 & 1,29 & 18 \\
\hline 13 Material elétrico e eletrônicos & 1,54 & 4 & 1,33 & 16 \\
\hline 14 Material de transporte & 1,50 & 6 & 1,34 & 12 \\
\hline 15 Indústrias diversas & 1,37 & 13 & 1,20 & 23 \\
\hline 16 Eletricidade e gás & 1,64 & 2 & 1,47 & 1 \\
\hline 17 Construçãoo & 1,25 & 24 & 1,33 & 14 \\
\hline 18 Comércio & 1,28 & 20 & 1,33 & 17 \\
\hline 19 Transporte & 1,44 & 8 & 1,39 & 8 \\
\hline 20 Serviços privados & 1,34 & 18 & 1,45 & 4 \\
\hline 21 Financeira e seguros & 1,36 & 15 & 1,42 & 6 \\
\hline 22 Imobiliários & 1,06 & 26 & 1,10 & 26 \\
\hline 23 Alojamento & 1,34 & 17 & 1,27 & 19 \\
\hline 24 Educação & 1,22 & 25 & 1,23 & 22 \\
\hline 25 Saúde & 1,33 & 19 & 1,33 & 13 \\
\hline 26 Administração & 1,28 & 22 & 1,26 & 20 \\
\hline
\end{tabular}

Fonte: Elaboração dos autores.

No ano de 2008, os setores que apresentaram os maiores multiplicadores de produçáo foram Refino de Petróleo (7), Eletricidade e gás (16), Artigos de borracha (9) e Material elétrico e eletrônicos (13). Dessa forma, o aumento de um milháo de reais na demanda final do setor de Petróleo, gera um aumento de 1,83 milhão de reais da produçáo na economia de forma direta e indireta. $\mathrm{O}$ setor petrolífero, portanto, era o setor que mais gerava efeitos de transbordamento na economia.

Para 2011, os setores que se destacaram foram Eletricidade e gás (16), Mineração (3), Cimento (10) e Serviços privados (20). Para o setor de Eletricidade e gás, temos que para 
cada aumento de uma unidade monetária em sua demanda final, é gerado o incremento de 1,47 unidades monetárias na economia fluminense.

De forma geral, ao comparar os resultados dos dois anos, os setores apresentaram valores menores em 2011. O resultado deve ser ressaltado, pois pode estar relacionado aos efeitos negativos que a crise financeira mundial provocou na economia nacional que, por sua vez, impactou na economia fluminense. Além da crise, o setor petrolífero também sofreu diversas consequências devido à legislação vigente que vinha sendo discutida deste a descoberta do Pré-sal e que impedia novos investimentos e ao controle de preços efetuado pelo Governo Federal.

Os baixos resultados do ano de 2011 foram consequência de uma menor quantidade de investimentos realizados, em relação à grande demanda por capital para suprir a grande área do Pré-sal. Elevaçóes nos custos e atrasos foram decorrentes da exclusividade da Petrobras sobre a exploração, impedindo assim investimentos privados no setor, juntamente com uma exigência da utilizaçáo de bens e serviços de origem nacional. Somado a tudo isso, a demora da escolha da melhor legislação e barreiras burocráticas inviabilizaram a realização de novos leilóes de áreas exploratórias de 2009 a 2012 (MORAIS, 2018).

A diminuição dos investimentos também teve por causa o controle dos preços do petróleo por parte do governo federal, o que gerou uma dívida para a Petrobras de US\$ 41 bilhóes (de 2011 a 2014) devido aos altos custos com a compra de petróleo refinado, muito acima do comercializado no país, desestimulando também possíveis investidores privados (MORAIS, 2018).

Dessa forma, os resultados apontaram uma queda na participação do setor petrolífero, passando da $1^{\text {a }}$ colocação em 2008 para a $11^{\text {a }}$ em 2011, demonstrando que no cenário mais recente o setor gerou menos capacidade de influenciar o crescimento da produção dos demais setores da economia. Apesar do setor ter perdido a liderança no ranking do multiplicador de produção, ele possui grande importância na economia fluminense como verificado na seção anterior, com altos valores dos índices de ligação de Hirschman-Rasmussen.

\subsection{Matriz inter-regional de 2011 e Multiplicador do Valor Adicionado}

Com o intuito de observar os impactos do setor petrolífero em mais de uma região, foi utilizada a matriz das regiōes Rio de Janeiro e Restante do Brasil (RBR) de 2011. Através dessa matriz, foi possível verificar a importância que o estado possui no referido setor com a utilização do multiplicador do valor adicionado, assim como os efeitos provocados na economia brasileira com a realização dos leilóes da bacia do Pré-sal.

O Valor adicionado representa o valor agregado no processo de produção de cada setor, isto é, dado um impacto na produção, o valor adicionado demonstra a capacidade que cada setor tem de produzir mais valor agregado na economia. Segundo Guilhoto et al. (2010), o valor adicionado pode ser relacionado diretamente com a ideia de Produto Interno Bruto de cada setor. O multiplicador, como discutido na seção 3, é dado pelo somatório da multiplicação de cada elemento da matriz inversa de Leontief com a divisão do valor adicionado pela produção bruta de cada setor. Deste modo, temos os resultados dispostos na Tabela 4, mostrando as porcentagens do valor adicionado que ficam retidas na 
região de origem da produção e à proporção que é distribuída para a outra região quando há um choque na demanda final dos distintos setores.

Tabela 4 - Multiplicador do Valor Adicionado

\begin{tabular}{|c|c|c|c|c|}
\hline Setores & Resto d & rasil & Rio de & eiro \\
\hline 1 Agricultura & $97,4 \%$ & $2,6 \%$ & $8,3 \%$ & $91,7 \%$ \\
\hline 2 Pecuária e pesca & $97,4 \%$ & $2,6 \%$ & $18,3 \%$ & $81,7 \%$ \\
\hline 3 Mineração & $97,0 \%$ & $3,0 \%$ & $21,7 \%$ & $78,3 \%$ \\
\hline 4 Alimentos e bebidas & $96,2 \%$ & $3,8 \%$ & $36,5 \%$ & $63,5 \%$ \\
\hline 5 Têxtil e calçados & $97,5 \%$ & $2,5 \%$ & $26,5 \%$ & $73,5 \%$ \\
\hline 6 Madeira & $95,9 \%$ & $4,1 \%$ & $21,7 \%$ & $78,3 \%$ \\
\hline 7 Petróleo & $61,7 \%$ & $38,3 \%$ & $16,7 \%$ & $83,3 \%$ \\
\hline 8 Químicos & $92,7 \%$ & $7,3 \%$ & $26,1 \%$ & $73,9 \%$ \\
\hline 9 Artigos de borracha & $95,0 \%$ & $5,0 \%$ & $29,2 \%$ & $70,8 \%$ \\
\hline 10 Cimento & $94,5 \%$ & $5,5 \%$ & $34,9 \%$ & $65,1 \%$ \\
\hline 11 Metalurgia & $94,6 \%$ & $5,4 \%$ & $33,1 \%$ & $66,9 \%$ \\
\hline 12 Equipamentos & $96,2 \%$ & $3,8 \%$ & $31,4 \%$ & $68,6 \%$ \\
\hline 13 Material elétrico e eletrônicos & $96,2 \%$ & $3,8 \%$ & $32,8 \%$ & $67,2 \%$ \\
\hline 14 Material de transporte & $95,4 \%$ & $4,6 \%$ & $36,7 \%$ & $63,3 \%$ \\
\hline 15 Indústrias diversas & $97,5 \%$ & $2,5 \%$ & $23,8 \%$ & $76,2 \%$ \\
\hline 16 Eletricidade e gás & $95,4 \%$ & $4,6 \%$ & $12,2 \%$ & $87,8 \%$ \\
\hline 17 Construção & $97,0 \%$ & $3,0 \%$ & $23,9 \%$ & $76,1 \%$ \\
\hline 18 Comércio & $97,9 \%$ & $2,1 \%$ & $22,9 \%$ & $77,1 \%$ \\
\hline 19 Transporte & $93,4 \%$ & $6,6 \%$ & $12,7 \%$ & $87,3 \%$ \\
\hline 20 Serviços privados & $97,5 \%$ & $2,5 \%$ & $8,7 \%$ & $91,3 \%$ \\
\hline 21 Financeira e seguros & $98,2 \%$ & $1,8 \%$ & $9,8 \%$ & $90,2 \%$ \\
\hline 22 Imobiliários & $99,6 \%$ & $0,4 \%$ & $3,6 \%$ & $96,4 \%$ \\
\hline 23 Alojamento & $97,5 \%$ & $2,5 \%$ & $23,6 \%$ & $76,4 \%$ \\
\hline 24 Educação & $98,9 \%$ & $1,1 \%$ & $4,9 \%$ & $95,1 \%$ \\
\hline 25 Saúde & $98,3 \%$ & $1,7 \%$ & $10,9 \%$ & $89,1 \%$ \\
\hline 26 Administração & $98,6 \%$ & $1,4 \%$ & $6,9 \%$ & $93,1 \%$ \\
\hline
\end{tabular}

Fonte: Elaboração dos autores.

Na produção de petróleo da região Restante do Brasil, 61,7\% do aumento do valor adicionado fica retido entre o RBR e 38,3\% são transbordados para o estado do Rio de Janeiro. Vale destacar que o setor foi o único que apresentou um maior espraiamento para o estado, demonstrando que a regiáo é de fato muito importante quando se pensa neste setor, uma vez que há uma grande proporçáo da produção nacional escoando para o Rio de Janeiro.

Quando o choque é dado na demanda final do Rio de Janeiro - e.g. o aumento no investimento advindo dos leilóes das bacias de Pré-sal - os resultados se mostraram mais dissipados entre as duas regióes quando comparados com o aumento da produção do RBR. 
Os setores como Serviços Imobiliários (22), Educação (24), Administração (26), Agricultura (1), Serviços Privados (20) e Intermediação Financeira (21) não geraram muitos efeitos de espraiamento na região do RBR, uma vez que a maior parte do valor adicionado criado no estado fica na própria região, demonstrando que são setores de baixo transbordamento inter-regional.

O setor de Petróleo demonstrou que a maior parte do efeito causado pelo aumento da demanda final fica no próprio estado (83,3\%), enquanto $16,7 \%$ são escoados para o restante do Brasil. Isso demonstra que grande parte da produção do setor é distribuída internamente, reforçando o poder do setor perante o estado.

\section{Consideraçóes finais}

O estado fluminense detém $78 \%$ da produção total de petróleo e $59 \%$ da produção de gás natural do Brasil de acordo com a ANP (2020). Além disso, o estado terá um aumento nos investimentos do setor petrolífero devido a leilóes que serão realizados pela União nas áreas do Pré-sal, o que trará um aumento de volume nos investimentos na cadeia produtiva do setor.

Com o intuito de elucidar a estrutura setorial do Rio de Janeiro, o presente artigo buscou avaliar os efeitos dos investimentos na cadeia petrolífera na economia brasileira, dando ênfase ao estado do Rio de Janeiro. Para isso, utilizou a metodologia de insumoproduto, pois a mesma permite analisar os efeitos inter e intra setoriais do aumento nos investimentos na cadeia produtiva. Além disso, é capaz de verificar os efeitos de spillover que a maior demanda na produção provoca, de forma direta e indireta, nas demais regióes do país. Assim, o artigo contribuiu ao fazer uma análise da estrutura produtiva fluminense provendo informações que facilitam os entes públicos e privados fazer um planejamento que considere os pontos fortes e fracos do estado.

Os resultados encontrados no estudo indicaram que, para 2008, o setor petrolífero se mostrou muito influente na economia fluminense através de suas compras de insumos dos demais setores do estado. No ano de 2011, o setor teve uma modificação em sua estrutura e se destacou mais quanto a seu fluxo de oferta. Nos dois anos, o setor se caracterizou como chave para a economia fluminense, influenciando o estado através de seu poder de compras e vendas de insumos.

De modo geral, o ano de 2011 apresentou menores efeitos na economia quando comparado a 2008, o que pode estar associado às perturbaçóes econômicas do período. A demora da escolha de uma nova legislação que amparasse a exploração do Pré-sal e o controle de preços feito pelo governo federal parecem ter diminuído os investimentos do setor, impactando negativamente em seus resultados.

Foi percebido, ainda, que o crescimento na demanda final do setor petrolífero da regiáo restante do Brasil levou a que boa parte do valor adicionado criado transbordasse para o Rio de Janeiro, isto é, 38\% do valor adicionado gerado no RBR escoou para o estado, enquanto, no caso de aumento na variação da produção do Rio de Janeiro, 83\% se mantiveram no próprio estado, e apenas $17 \%$ se destinou para os demais. 
Mostra-se importante, para trabalhos futuros, verificar se os investimentos advindos dos leilóes foram traduzidos em crescimento de empregos e salários no estado. Além disso, é necessário analisar como o choque positivo na demanda final impactou na receita dos municípios e na do estado e se esse crescimento refletiu em melhoria nos índices de desenvolvimento econômico.

\section{Referências:}

AGÊNCIA ESTADUAL DE PLANEJAMENTO E PESQUISAS DE PERNAMBUCO. CONDEPE/FIDEM. Estudos dos impactos dos investimentos na economia pernambucana: Unidades da BR FOODS, HEMOBRÁS, Estaleiro Atlântico Sul, Petroquímica Suape e Refinaria Abreu e Lima: uma visão a partir da Matriz InsumoProduto de Pernambuco - 2005. Recife, 2011.

AGÊNCIA NACIONAL DE PETROLEO, GÁS NATURAL E BIOCOMBUSTÍVEIS (ANP). As Rodadas de Licitaçóes. [S.I.], 8 nov. 2017. Disponível em: <http://rodadas. anp.gov.br/pt/entenda-as-rodadas/as-rodadas-de-licitacoes>. Acesso em: jan. 2021.

Os Regimes de Concessão e Partilha. [S.I.], 24 out. 2017. Disponível em: <http://rodadas.anp.gov.br/pt/entenda-as-rodadas/os-regimes-de-concessao-e-de-partilha>. Acesso em: dez. 2020.

. Resultados. [S.I.], 8 jan. 2018. Disponível em: <http://rodadas.anp.gov.br/pt/ resultados>. Acesso em: nov. 2020.

. Especial ANP 20 anos. [S.I.], 26 fev. 2019. Disponível em: <http://www.anp.gov. br/institucional/especial-anp-20-anos>. Acesso em: dez. 2020.

. Anuário Estatístico Brasileiro do Petróleo, Gás Natural e Biocombustíveis

2020. Disponível em: https://www.gov.br/anp/pt-br/centrais-de-conteudo/dados-abertos/ anuario-estatistico-2020-dados-abertos. Acesso em: dez. 2020.

BELTRÃO, R. L. C. et al. Challenges and new technologies for the development of the presalt cluster, Santos Basin, Brazil. In: Offshore Technology Conference, 2009, Texas, USA. 11p.

BOZELLI, R. L. et al. Impactos Ambientais da Exploração e Produção de Petróleo na Bacia de Campos, RJ. In: IV Encontro Nacional da Anppas, 2008, Brasília- DF. 2008.

BRASIL. Lei no 11.445, de 5 de janeiro de 2007. Estabelece diretrizes nacionais para o saneamento básico e dá outras providencias. Brasília: Congresso Nacional, 2007.

Disponível em: <http:/www.planalto.gov.br/ccivil_03/_ato2007-2010/2007/lei/111445. htm>. Acesso em: dez. 2020. 
Lei no 12.351, de 22 de dezembro de 2010. Dispóe sobre a exploração e a produção de petróleo, de gás natural e de outros hidrocarbonetos fluidos, sob o regime de partilha de produção, em áreas do pré-sal e em áreas estratégicas e dá outras providencias. Brasília: Congresso Federal, 2010. Disponível em: <http://www.planalto.gov.br/ ccivil_03/_Ato2007-2010/2010/Lei/L12351.htm>. Acesso em: nov. 2020.

. Lei no 13.365, de 29 de novembro de 2016. Faculta à Petrobras o direito de preferência para atuar como operador e possuir participação mínima de 30\% nos consórcios formados para exploração de blocos licitados no regime de partilha de produção. Brasília: Congresso Federal, 2016. Disponível em: <http://www.planalto.gov. br/ccivil_03/_Ato2015-2018/2016/Lei/L13365.htm>. Acesso em: nov. 2020.

BRESSER-PEREIRA, L. C. O conceito histórico de desenvolvimento econômico. Textos para Discussão 157, Escola de Economia de São Paulo da Fundação Getúlio Vargas FGV (EESP), São Paulo, dez. 2006.

BULMER-THOMAS, V. Input-Output Analysis in Developing Countries Sources, Methods and Applications. New York: Wiley, 1982. 297p.

CASIMIRO FILHO, F. Contribuiçóes do Turismo à Economia Brasileira. 2002. 240

f. Tese (Doutorado em Ciências na área de Economia Aplicada) - Escola Superior de Agricultura Luiz de Queiroz, Universidade de São Paulo, Piracicaba, 2002.

CRUZ, J. L. V. da. Emprego, crescimento e desenvolvimento econômico: notas sobre um caso regional. Boletim Técnico do Senac, [S.I.], v. 29, n. 1, p. 28-39, mai. 2018.

DIAS, J. L. de M.; QUAGLINO, M. A. A questáo do petróleo no Brasil: uma história da Petrobrás. Rio de Janeiro: CPDOC: PETROBRAS, 1993. 211 p.

DEPARTAMENTO INTERSINDICAL DE ESTATÍSTICA E ESTUDOS SOCIECONÔMICOS (DIEESE). Estudo Setorial da Construção - 2012. Estudos e pesquisas, no 65, mai. de 2013.

FERNANDES, C. F. A Evoluçáo da Arrecadaçáo de Royalties do Petróleo no Brasil e seu Impacto sobre o Desenvolvimento Econômico do Estado do Rio de Janeiro. 2007. 72f. Trabalho de conclusão de curso (Bacharelado em Economia) - Instituto de Economia, Universidade Federal do Rio de Janeiro, Rio de Janeiro, 2007.

FURTADO, A. T. Pré-sal, Desenvolvimento Industrial e Inovação. Revista Paranaense de Desenvolvimento-RPD, Curitiba, v. 34, n. 125, p. 79-100, jul./dez. 2013.

GUILHOTO, J.J.M., C.R. AZZONI, S.M. ICHIHARA, D.K. KADOTA, E.A. HADDAD. Matriz de Insumo-Produto do Nordeste e Estados: Metodologia e Resultados. Fortaleza: Banco do Nordeste do Brasil. ISBN: 978.85.7791.110.3. 289 p., 2010 . 
GUILHOTO, J. J. M. Input-Output Analysis: Theory and Foundations. Munich Personal RePEc Archive, São Paulo, 2011.

HADDAD, E. A., GONÇALVES Jr, C.A., NASCIMENTO, T. B. Matriz Interestadual de Insumo-Produto para o Brasil: Uma Aplicação do Método IIOAS. Revista Brasileira de Estudos Regionais e Urbanos (RBERU), v. 11, n. 4, pp. 424-446, 2017.

HIRSCHMAN, A. O. The strategy of economic development. Yale University Press, 1958.

IBGE. INSTITUTO BRASILEIRO DE GEOGRAFIA E ESTATÍSTICAS. Estatísticas. Contas Nacionais. 2021.

INSTITUTO JONES DOS SANTOS NEVES (IJSN). Tabela de Recursos e Usos e Matriz de Insumo-Produto do Espírito Santo - 2015. Texto para Discussáo. Vitória, ES, 2020 .

LEIVAS, P. H.; FEIJÓ, F. T. Estrutura produtiva e multiplicadores de impacto intersetorial do Conselho Regional de Desenvolvimento da Região Sul (Corede Sul) do Rio Grande do Sul: uma análise insumo-produto. Ensaios FEE, Porto Alegre, v. 35, n. 2, p. 521-554, dez. 2014.

LEONTIEF, W. The Structure of American Economy, 1919-1929. Cambridge: Harvard University Press, MA, 1941.

MARTINS, S. S. da S. et al. Produção de petróleo e impactos ambientais: algumas consideraçóes. Revista Holos, Rio Grande do Norte, v. 6, p. 54-76, 2015.

MILLER, R. E.; BLAIR, P. D. Input-Output Analysis: Foundations and Extensions. New York: Cambridge University Press, 2009.

MINISTÉRIO DE ECONOMIA (ME): INDÚSTRIA, COMÉRCIO EXTERIOR E SERVIÇOS. Comex Vis: Estado - Rio de Janeiro. [S.I.], [ca. 2018]. Disponível em: <http://www.mdic.gov.br/comercio-exterior/estatisticas-de-comercio-exterior/comex-vis/ frame-uf-produto? uf=rj> Acesso em: dez. 2020.

MORAIS, J. M. Petróleo em águas profundas: uma história tecnológica da Petrobras na exploração e produção offshore. Brasília: Ipea: Petrobras, 2013.

. A crise no setor de petróleo e gás natural no Brasil e as açóes para o retorno dos investimentos. In: DE NEGRI, João Alberto; ARAÚJO, Bruno César; 2018.

NOBREGA, L. K.; TAQUES, F. H.; DE OLIVEIRA, J. da C. T. Análise InsumoProduto: Um estudo para o Brasil a partir da Cesta Básica. 2014. 
OLIVEIRA, C. W. de A. et al. Impactos macroeconômicos de investimentos na cadeia de petróleo brasileira. Texto para Discussão n. 1657, IPEA, Brasília, ago. 2011.

PACHECO, C. A. G. A aplicaçáo e o impacto dos royalties do petróleo no desenvolvimento econômico dos municípios confrontantes da Bacia de Campos. 2003. Trabalho de conclusão de curso (Bacharelado em Economia) - Instituto de Economia, Universidade Federal do Rio de Janeiro, Rio de Janeiro, 2003.

PEREIRA, E. M. O Ouro Negro: Petróleo e suas crises políticas, econômicas, sociais e ambientais na $2^{\text {a }}$ metade do século XX. Outros Tempos-Pesquisa em Foco-História, Maranhão, v. 5, n. 6, p. 54-72, dez. 2008.

PEROBELLI, F. S.; VALE, V. A.; PIRES, M. M.; SANTOS, J. P. C.; ARAÚJO JÚNIOR, I. F. Análise sistêmica da estrutura produtiva da Bahia para o ano de 2009. In: Anais. XI Encontro de Economia Baiana. Salvador-Bahia, 2015.

PIQUET, R. P. da. S. O lugar do regional na indústria do petróleo. Revista Brasileira de Estudos Urbanos e Regionais, Rio de Janeiro, v. 14, n. 1, p. 51-63, mai. 2012.

POSTALI, F. A. S. Rendas do Petróleo e Ineficiências Administrativas nos Municípios Brasileiros. 2012. 122f. Tese (Doutorado para livre-docência em Economia) - Faculdade de Economia, Administração e Contabilidade, Universidade de São Paulo, São Paulo, 2012.

RASMUSSEN, P. N. Studies in Intersectorial Relations. Amsterdam, North-Holland, P.C. 1956.

RODRIGUEZ, M. R.; COLELA JR, O.; SUSLICK, S. B. Os processos de licitação de áreas exploratórias e áreas inativas com acumulaçóes marginais no Brasil. Revista Brasileira de Geociências, São Paulo, v. 38, n. 2 suppl, p. 63-79, jun. 2008.

SILVA, R. D. da. Rio de Janeiro: Crescimento, Transformaçóes e sua Importância para a Economia Nacional (1930-2000). 2004. 180 f. Dissertação (Mestrado em Ciências Econômicas) - Instituto de Economia, Universidade Estadual de Campinas, Campinas, 2004.

SILVA, M. C. da. Impactos macroeconômicos da descoberta do Pré-Sal. 2015. $44 f$. Trabalho de conclusão de curso (Bacharelado em Economia) - Instituto de Economia, Universidade Federal do Rio de Janeiro, Rio de Janeiro, 2015.

SILVA, M. O. Trajetória e perspectivas do estado do rio de janeiro no cenário de megaeventos. In: Seminário de Pesquisa do Instituto de Economia da UFRJ. 2006. 
TAKASAGO, M.; MOLLO, M. L. R.; GUILHOTO, J. J. M. O Debate

desenvolvimentista no Brasil: discutindo resultados da matriz de insumo-produto.

Planejamento e políticas públicas | ppp | n. 48 | jan./jun. 2017.

TOLMASQUIM, M. T.; GUERREIRO, A.; GORINI, R. Matriz energética brasileira: uma prospectiva. Novos estudos CEBRAP, São Paulo, n. 79, p. 47-69, nov. 2007.

VIEIRA FILHO, J. E. R.; FISHLOW, A. Agricultura e indústria no Brasil: inovação e competitividade. $1^{\text {a }}$ ed. Brasília: Ipea, 2017. 305p.

\section{ANEXO}

Tabela A 1 - Agregação de setores

\begin{tabular}{|c|c|c|}
\hline Setores & Setores Matriz 2008 & Setores Matriz 2011 \\
\hline \multirow{2}{*}{1 Agricultura } & \multirow{2}{*}{$\begin{array}{l}\text { Agricultura, } \\
\text { silvicultura, } \\
\text { exploração florestal }\end{array}$} & Agricultura, inclusive o apoio à agricultura e a pós-colheita \\
\hline & & Produçâo florestal; pesca e aquicultura \\
\hline 2 Pecuária e pesca & Pecuária e pesca & Pecuária, inclusive o apoio à pecuária \\
\hline \multirow{3}{*}{3 Mineração } & \multirow{3}{*}{ Mineração } & Extração de carvão mineral e de minerais não-metálicos \\
\hline & & $\begin{array}{l}\text { Extração de minério de ferro, inclusive beneficiamentos e a } \\
\text { aglomeração }\end{array}$ \\
\hline & & $\begin{array}{l}\text { Extração de minerais metálicos náo-ferrosos, inclusive } \\
\text { beneficiamentos }\end{array}$ \\
\hline \multirow{5}{*}{4 Alimentos e bebidas } & \multirow{5}{*}{$\begin{array}{l}\text { Alimentos, bebidas e } \\
\text { fumo }\end{array}$} & $\begin{array}{l}\text { Abate e produtos de carne, inclusive os produtos do laticínio } \\
\text { e da pesca }\end{array}$ \\
\hline & & Fabricação e refino de açúcar \\
\hline & & Outros produtos alimentares \\
\hline & & Fabricaçáo de bebidas \\
\hline & & Fabricação de produtos do fumo \\
\hline \multirow{3}{*}{5 Têxtil e calçados } & \multirow{3}{*}{$\begin{array}{l}\text { Têxtil, vestuário e } \\
\text { calçados }\end{array}$} & Fabricação de produtos têxteis \\
\hline & & Confecção de artefatos do vestuário e acessórios \\
\hline & & Fabricação de calçados e de artefatos de couro \\
\hline \multirow{3}{*}{6 Madeira } & \multirow{3}{*}{$\begin{array}{l}\text { Madeira, papel e } \\
\text { impressáo }\end{array}$} & Fabricação de produtos da madeira \\
\hline & & Fabricação de celulose, papel e produtos de papel \\
\hline & & Impressão e reprodução de gravações \\
\hline \multirow{2}{*}{7 Petróleo } & \multirow{2}{*}{$\begin{array}{l}\text { Refino de petróleo, } \\
\text { coque e álcool }\end{array}$} & Extração de petróleo e gás, inclusive as atividades de apoio \\
\hline & & Refino de petróleo e coquerias \\
\hline
\end{tabular}




\begin{tabular}{|c|c|c|}
\hline Setores & Setores Matriz 2008 & Setores Matriz 2011 \\
\hline \multirow{5}{*}{8 Químicos } & \multirow{5}{*}{$\begin{array}{l}\text { Outros produtos } \\
\text { químicos e } \\
\text { farmacêuticos }\end{array}$} & Fabricaçáo de biocombustíveis \\
\hline & & $\begin{array}{l}\text { Fabricaçáo de químicos orgânicos e inorgânicos, resinas e } \\
\text { elastômeros }\end{array}$ \\
\hline & & $\begin{array}{l}\text { Fabricaçáa de defensivos, desinfestantes, tintas e químicos } \\
\text { diversos }\end{array}$ \\
\hline & & $\begin{array}{l}\text { Fabricaçáo de produtos de limpeza, cosméticos/perfumaria e } \\
\text { higiene pessoal }\end{array}$ \\
\hline & & Fabricação de produtos farmoquímicos e farmacêuticos \\
\hline 9 Artigos de borracha & $\begin{array}{l}\text { Artigos de borracha e } \\
\text { plástico }\end{array}$ & Fabricaçáo de produtos de borracha e de material plástico \\
\hline \multirow[b]{2}{*}{10 Cimento } & \multirow{2}{*}{$\begin{array}{l}\text { Cimento e outros } \\
\text { produtos de minerais } \\
\text { náo-metálicos }\end{array}$} & Fabricação de produtos de minerais não-metálicos \\
\hline & & $\begin{array}{l}\text { Produção de ferro-gusa/ferroligas, siderurgia e tubos de aço } \\
\text { sem costura }\end{array}$ \\
\hline 11 Metalurgia & Metalurgia & Metalurgia de metais náo-ferosos e a fundição de metais \\
\hline \multirow[b]{2}{*}{12 Equipamentos } & \multirow{2}{*}{$\begin{array}{l}\text { Máquinas e } \\
\text { equipamentos }\end{array}$} & Fabricação de máquinas e equipamentos mecânicos \\
\hline & & $\begin{array}{l}\text { Fabricaçáo de outros equipamentos de transporte, exceto } \\
\text { veículos automotores }\end{array}$ \\
\hline \multirow{2}{*}{$\begin{array}{l}13 \text { Material elétrico e } \\
\text { eletrônicos }\end{array}$} & \multirow{2}{*}{$\begin{array}{l}\text { Material elétrico e } \\
\text { eletrônicos }\end{array}$} & $\begin{array}{l}\text { Fabricaçáo de equipamentos de informática, produtos } \\
\text { eletrônicos e ópticos }\end{array}$ \\
\hline & & Fabricação de máquinas e equipamentos elétricos \\
\hline \multirow{3}{*}{$\begin{array}{l}14 \text { Material de } \\
\text { Transporte }\end{array}$} & \multirow{3}{*}{$\begin{array}{l}\text { Material de } \\
\text { transporte }\end{array}$} & $\begin{array}{l}\text { Fabricaçáo de produtos de metal, exceto máquinas e } \\
\text { equipamentos }\end{array}$ \\
\hline & & Fabricação de automóveis, caminhóes e ônibus, exceto peças \\
\hline & & Fabricação de peças e acessórios para veículos automotores \\
\hline \multirow[b]{2}{*}{15 Indústrias diversas } & \multirow[b]{2}{*}{ Indústrias diversas } & Fabricação de móveis e de produtos de indústrias diversas \\
\hline & & $\begin{array}{l}\text { Manutenção, reparação e instalação de máquinas e } \\
\text { equipamentos }\end{array}$ \\
\hline \multirow[b]{2}{*}{16 Eletricidade e gás } & \multirow{2}{*}{$\begin{array}{l}\text { Eletricidade e gás, } \\
\text { água, esgoto e } \\
\text { limpeza urbana } \\
\end{array}$} & Energia elétrica, gás natural e outras utilidades \\
\hline & & Água, esgoto e gestão de resíduos \\
\hline 17 Construção & Construção & Construção \\
\hline \multirow{2}{*}{18 Comércio } & \multirow{2}{*}{ Comércio } & $\begin{array}{l}\text { Comércio e reparação de veículos automotores e } \\
\text { motocicletas }\end{array}$ \\
\hline & & $\begin{array}{l}\text { Comércio por atacado e a varejo, exceto veículos } \\
\text { automotores }\end{array}$ \\
\hline \multirow{4}{*}{19 Transporte } & \multirow{4}{*}{$\begin{array}{l}\text { Transporte, } \\
\text { armazenagem e } \\
\text { correio }\end{array}$} & Transporte terrestre \\
\hline & & Transporte aquaviário \\
\hline & & Transporte aéreo \\
\hline & & $\begin{array}{l}\text { Armazenamento, atividades auxiliares dos transportes e } \\
\text { correio }\end{array}$ \\
\hline
\end{tabular}




\begin{tabular}{|c|c|c|}
\hline Setores & Setores Matriz 2008 & Setores Matriz 2011 \\
\hline \multirow{7}{*}{20 Serviços privados } & \multirow{7}{*}{ Serviços privados } & Edição e edição integrada à impressão \\
\hline & & $\begin{array}{l}\text { Atividades de televisão, rádio, cinema e gravação/ediçáo de } \\
\text { som e imagem }\end{array}$ \\
\hline & & Telecomunicaçóes \\
\hline & & $\begin{array}{l}\text { Desenvolvimento de sistemas e outros serviços de } \\
\text { informaçáo }\end{array}$ \\
\hline & & $\begin{array}{l}\text { Atividades jurídicas, contábeis, consultoria e sedes de } \\
\text { empresas }\end{array}$ \\
\hline & & $\begin{array}{l}\text { Serviços de arquitetura, engenharia, testes/análises técnicas } \\
\text { e P \& D }\end{array}$ \\
\hline & & Outras atividades profissionais, científicas e técnicas \\
\hline $\begin{array}{l}21 \text { Financeira e } \\
\text { seguros }\end{array}$ & $\begin{array}{l}\text { Intermediaçáo } \\
\text { financeira e seguros }\end{array}$ & $\begin{array}{l}\text { Intermediação financeira, seguros e previdência } \\
\text { complementar }\end{array}$ \\
\hline \multirow[b]{2}{*}{22 Imobiliários } & \multirow{2}{*}{$\begin{array}{l}\text { Serviços imobiliários } \\
\text { e aluguel }\end{array}$} & Atividades imobiliárias \\
\hline & & $\begin{array}{l}\text { Aluguéis não-imobiliários e gestáo de ativos de propriedade } \\
\text { intelectual }\end{array}$ \\
\hline \multirow{2}{*}{23 Alojamento } & \multirow{2}{*}{$\begin{array}{l}\text { Serviços de } \\
\text { alojamento e } \\
\text { alimentaçáo }\end{array}$} & Alojamento \\
\hline & & Alimentação \\
\hline \multirow{2}{*}{24 Educação } & \multirow{2}{*}{$\begin{array}{l}\text { Educação mercantil e } \\
\text { pública }\end{array}$} & Educação pública \\
\hline & & Educação privada \\
\hline \multirow{2}{*}{25 Saúde } & \multirow{2}{*}{$\begin{array}{l}\text { Saúde mercantil e } \\
\text { pública }\end{array}$} & Saúde pública \\
\hline & & Saúde privada \\
\hline 26 Administração & $\begin{array}{l}\text { Administração } \\
\text { pública e seguridade } \\
\text { social. }\end{array}$ & Administração pública, defesa e seguridade social \\
\hline
\end{tabular}

Fonte: Elaboração dos autores. 